\title{
PARENTAL ORIGIN AND MECHANISM OF FORMATION OF X CHROMOSOME STRUC- TURAL ABNORMALITIES: FOUR CASES DETERMINED WITH RFLPS
}

\author{
Han-Xiang Deng, ${ }^{1,2}$ Jia-Hui XIA, ${ }^{2}$ Mutsuo Ishikawa, ${ }^{3}$ \\ and Norio NIIKAWA ${ }^{1}$ \\ ${ }^{1}$ Department of Human Genetics, Nagasaki University School of Medicine, \\ Sakamoto-machi, Nagasaki 852, Japan \\ ${ }^{2}$ National Laboratory of Medical Genetics, Hunan Medical University, \\ Changsha, Hunan, China \\ ${ }^{3}$ Department of Gynecology and Obstetrics, Asahikawa Medical College, \\ Nishikagura, Asahikawa 078, Japan
}

\begin{abstract}
Summary Parental origin and mechanism of formation of $\mathrm{X}$ chromosome structural anbormalities were studied in one each case of $\operatorname{dup}(X)(\mathrm{pter} \rightarrow$ p11.4::p22.1 $\rightarrow$ qter $), \quad \operatorname{del}(X)(q$ ter $\rightarrow$ p 11: $), \quad$ i(X)(qter $\rightarrow$ cen $\rightarrow$ qter $),$ and inv dup $(X)$ (pter $\rightarrow \mathrm{q} 22:: \mathrm{q} 22 \rightarrow$ pter) using various $X$-linked RFLPs as genetic markers. Segregation and densitometric analyses on polymorphic DNAs revealed that the $\operatorname{dup}(\mathrm{Xp})$ and the $\operatorname{del}(\mathrm{Xp})$ are both of paternal origin and the $i(X q)$ and $i \operatorname{dic}(X)$ are of maternal origin. The $\operatorname{dup}(X p)$ had arisen by an unequal sister chromatid exchange and the del(Xp) had occurred through an intrachromosomal breakage-reunion mechanism, both in the paternal $X$ chromosome. The $\mathrm{i}(\mathrm{Xq})$ had arisen either through centromere fission of a maternal X chromosome, followed by duplication of its long-arm, or through a translocation between two maternal $X$ chromosomes after meiotic crossing-over. The $\operatorname{inv} \operatorname{dup}(\mathrm{X})$ arose through sister chromatid breakage and reunion in a maternal $\mathrm{X}$ chromosome. These results, together with those of previous studies, suggest that the de novo abnormalities due to events involving centromere disruption arise predominantly during oogenesis, while those due to simple breakage-reunion events occur preferentially during spermatogenesis.
\end{abstract}

\section{INTRODUCTION}

Parental origin and mechanism of formation of chromosome abnormalities in man have been studied mainly in the autosomes, especially in the acrocentric chromosomes and a few other chromosomes that bear heteromorphic cytogenetic markers

Received June 15, 1990; revised version received July 5, 1990; Accepted July 9, 1990. 
useful for segregation analysis (cf. Magenis, 1988, for reference). It has been demonstrated that autosomal trisomies are predominantly maternal in origin (Juberg and Morey, 1983; Ishikiriyama and Niikawa, 1984; Hassold and Jacobs, 1984; Hassold et al., 1984). On the other hand, the origin of autosomal structural abnormalities other than Robertsonian translocations are preferentially paternal (Chamberlin and Magenis, 1980; Olson and Magenis, 1988). In contrast, there is a dearth of information on the origin of structural abnormalities of the $\mathrm{X}$ chromosome, mainly due to the lack of its cytogenetic markers. A few studies that employed RFLPs (restriction fragment length polymorphisms) as markers, however, were successful in tracing their origin. They included preferential paternal sex-chromosome loss in 35 cases of monosomy X (Hassold et al., 1988) and chromatid breakage and reunion of sister chromatids at the breakpoint in three cases of dicentric X chromosome (Phelan et al., 1988).

We ascertained the parental origin and the mechanism of formation in four cases of $\mathrm{X}$ chromosome structural abnormalities by segregation and gene-dose analyses using X-linked RFLPs.

\section{MATERIALS AND METHODS}

Cases. Patient I, a three-year-old Chinese girl, has mental retardation, hypertelorism, low-set ears, a high-arched palate and a 46,X,dup $(X)($ pter $\rightarrow$ p 11.4::p22.1 $\rightarrow$ qter) karyotype. Patient II is a 22-year-old Chinese woman with a $46, \mathrm{X}, \mathrm{del}(\mathrm{X})$ (qter $\rightarrow$ p11:) karyotype. Patient III is a 13-year-old Chinese girl with a $46, X, i(X)$ (qter $\rightarrow$ cen $\rightarrow$ qter) karyotype. Both patients II and III have the stigmata of Turner syndrome. Patient IV is a 15-year-old Japanese girl with primary amenorrhea and cleft palate, and has a $46, X$, inv $\operatorname{dup}(X)($ pter $\rightarrow q 22:: q 22 \rightarrow$ pter $)$ karyotype.

Southern blot analyses. Genomic DNAs were extracted from peripheral blood leukocytes of the four patients and their parents. DNA samples were digested with various endonucleases of interest, according to the supplier specifications. Electrophoresis, Southern blotting, hybridization, autoradiography, and all other experiments were performed according to the standard techniques. The following 14 probes, mapped at various regions of the $\mathrm{X}$ chromosome, were employed in this study: L782 (the identified locus, DXS85; located at Xp22.3-p22.2); p99-6 (DXS41; Xp22.1); cDMD1a (DMD; Xp21.3-p21.1); P20 (DXS269; Xp21.2); pERT87-1 and pERT87-15 (DXS164; Xp21.2); J-Bir (DXS270; Xp21.2); L754 and 754-11 (DXS84; Xp21.1); p22-33 (DXS11; Xq24-q25); pDSK1 (HPRT; Xq26); p482.6 (F8C; Xq28); DX13 (DXS15; Xq28); St14-1 (DXS52; Xq28). The RFLPs already detected with these probes (Mandel et al., 1989) and our newly found cDMD1a/PvuII RFLPs (Deng and Niikawa, 1990) were used as markers for segregation analyses. Gene doses of polymorphic and constant autoradiographic bands were determined by densitometry as described previously (Kondoh et al., 1988). 


\section{Patient I}

\section{RESULTS}

Probes/enzymes used included cDMD1a/PvuII, 754-11/EcoRI, L754/Pst I, J-Bir/BamHI, pERT87-1/XmnI, pERT87-15/XmnI, L782/EcoRI, P20/EcoRV, and $\mathrm{P} 20 / \mathrm{Msp} \mathrm{I}$, all of which are localized at the Xp2l segment involved in duplication in this patient. The combination of cDMDla/PvulI gave two pairs of polymorphic alleles $(20 \mathrm{~kb} / 5.8 \mathrm{~kb}$, and $15 \mathrm{~kb} / 8 \mathrm{~kb})$ in this family (Fig. 1a). The father is hemi-

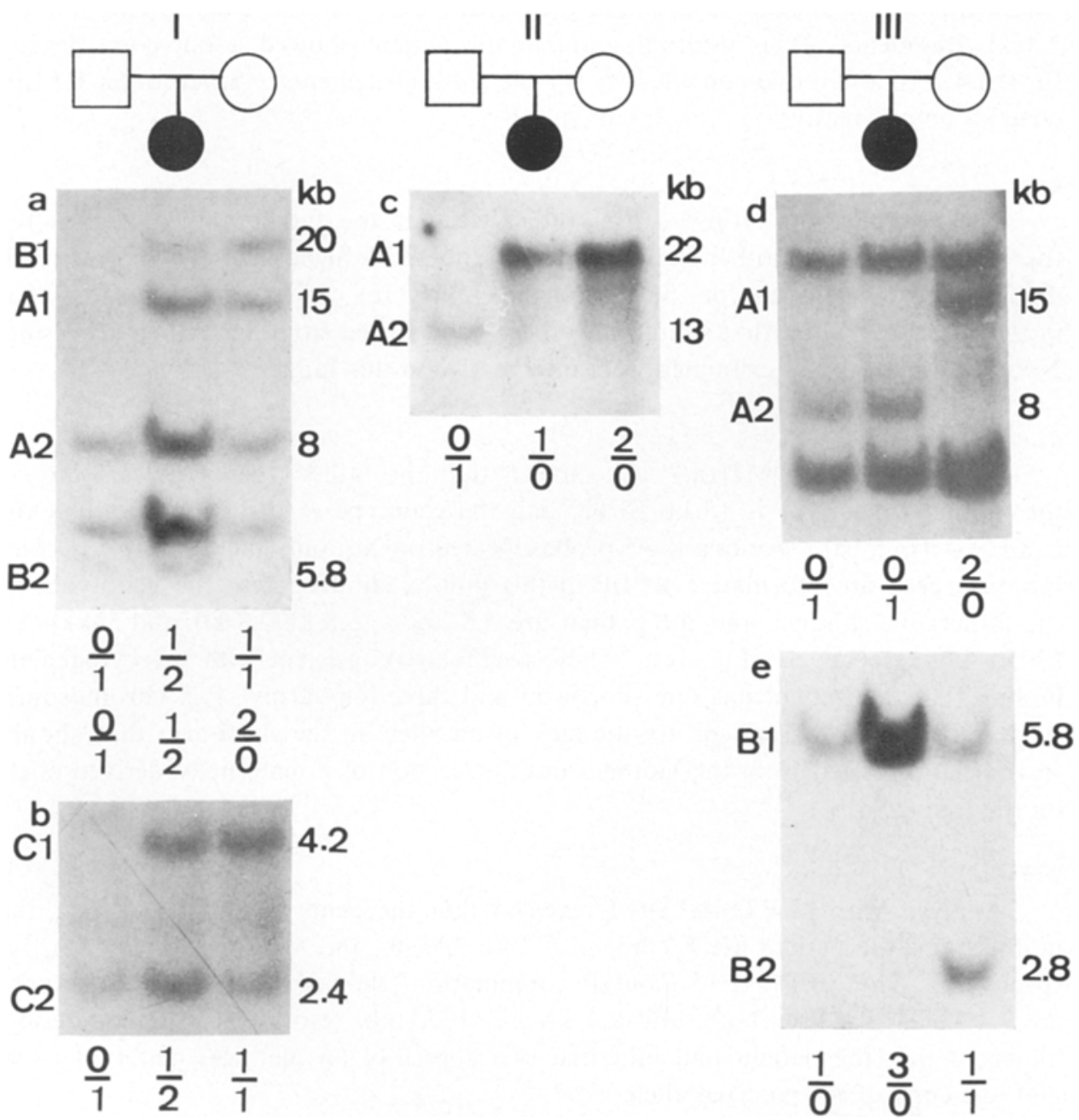

Fig. 1. RFLPs in patients I-III and their parents. Southern blots with cDMD1a/PvuII (a and d), 754-11/EcoRI (b), p99-6/Pst I (c), and with DX13/BglII (e). Copy numbers of alleles (1 and 2) of polymorphic DNA fragments in different loci (AC) in each family member is shown at the bottom of each lane. Fragment sizes are shown in $\mathrm{kb}$. 
zygous both for the $8 \mathrm{~kb}$ and for the $5.8 \mathrm{~kb}$ alleles, and the mother $15 \mathrm{~kb} / 8 \mathrm{~kb}$ heterozygous and $20 \mathrm{~kb} / 20 \mathrm{~kb}$ homozygous. The patient seemed double-heterozygous for the $20 \mathrm{~kb} / 5.8 \mathrm{~kb}$ and for the $15 \mathrm{~kb} / 8 \mathrm{~kb}$ alleles. Densitometric analysis of autoradiographic bands showed that the patient has three copies of the $6.4 \mathrm{~kb}$ constant band, two copies of the $8 \mathrm{~kb}$ and $5.8 \mathrm{~kb}$ polymorphic bands and one copy each of the $20 \mathrm{~kb}$ and $15 \mathrm{~kb}$ bands, indicating that her $5.8 \mathrm{~kb}$ allele had come from her father in duplicate. This finding was confirmed by the 754-11/EcoRI RFLPs (Fig. 1b). Analysis with $754-11 / E c o$ RI detected that the father is hemizygous for the $2.4 \mathrm{~kb}$ fragment, while both the mother and the patient were heterozygous for the $4.2 \mathrm{~kb} /$ $2.4 \mathrm{~kb}$ fragments. The autoradiogram in the patient showed a one-copy density for the $4.2 \mathrm{~kb}$ and a two-copy density for the $2.4 \mathrm{~kb}$ fragments. Seven other RFLPs were all uninformative.

\section{Patient II}

The combination of $p 99-6 / P s t \mathbf{l}$ indicated that the father is hemizygous for the $13 \mathrm{~kb}$ allele, the mother homozygous for the $22 \mathrm{~kb}$ allele, and the patient, with $\operatorname{del}(\mathrm{X})(\mathrm{p} 11)$, hemizygous for the $22 \mathrm{~kb}$ allele (Fig. Ic). The result indicated that in the patient an allele that should have been transmitted from her father is missing. None of other RFLPs examined were informative in this family.

\section{Patient III}

Analysis with cDMDla/PvuII showed that the father's genotype is $8 \mathrm{~kb} /-$, the mother's genotype is $15 \mathrm{~kb} / 15 \mathrm{~kb}$, and the genotype of the patient with $\mathrm{i}(\mathrm{Xq})$ is $8 \mathrm{~kb} /-$ (Fig. 1d). Among the 5 probes located on Xq, only the DX13/BglII combination gave an informative RFLP in this family, showing that the genotypes of the father, the mother, and the patient are $5.8 \mathrm{~kb} /-, 5.8 \mathrm{~kb} / 2.8 \mathrm{~kb}$, and $5.8 \mathrm{~kb} / 5.8$ $\mathrm{kb} / 5.8 \mathrm{~kb}$, respectively (Fig. 1e). These results are consistent with the cytogenetic finding that the patient has one short-arm and three long-arms of $\mathrm{X}$ chromosome. Also indicated in the patient are the lack of an allele in the short-arm that should have been inherited from the mother, and duplication of a maternally derived allele on the long-arm.

\section{Patient IV}

Analysis with pERT87-1/XmnI revealed that the genotypes of the father, the mother, and the patient are $8.7 \mathrm{~kb} /-, 8.7 \mathrm{~kb} / 7.5 \mathrm{~kb}$, and $8.7 \mathrm{~kb} / 7.5 \mathrm{~kb} / 7.5 \mathrm{~kb}$, respectively. The pERT87-15/BamHI combination showed that their genotypes are $7.1 \mathrm{~kb} /-, 9.4 \mathrm{~kb} / 7.1 \mathrm{~kb}$, and $9.4 \mathrm{~kb} / 9.4 \mathrm{~kb} / 7.1 \mathrm{~kb}$, respectively. These results indicated that the patient had inherited two copies of an identical maternal allele and one copy of the paternal allele.

\section{DISCUSSION}

The parental origin of structural abnormalities of the $\mathrm{X}$ chromosome was successfully ascertained in all four cases in the present study. Of the four cases, 
two $[\operatorname{dup}(\mathrm{Xp})$ and $\operatorname{del}(\mathrm{Xp})]$ were paternal, while the other two [inv $\operatorname{dup}(\mathrm{X})$ and $\mathrm{i}(\mathrm{Xq})]$ were maternal in origin. The mechanisms of formation in the first three cases may differ from that in the last case (Table 1). The $\operatorname{dup}(X)(\mathrm{p} 21)$ in patient I had arisen by an intrachromosomal exchange, an unequal exchange between the sister chromatids in the $\mathrm{X}$ chromosome of the father. Unequal sister chromatid exchange has been shown to form dicentric X-chromosomes (Phelan et al., 1988) and repeatedly implicated as the mechanism for direct duplication of a chromosome segment (Van Dyke, 1988), and gene duplication or gene amplification (Stewart et al., 1989; Stark et al., 1989). The $\operatorname{del}(\mathrm{X})(\mathrm{p} 11)$ in patient II had also occurred through intrachromosomal breaks during paternal spermatogenesis. Since these two abnormalities are due to simple breakage-reunion events within a chromosome arm, the assumption that they are of paternal origin seems reasonable. It is consistent with the previous finding that de novo autosomal structural abnormalities other than Robertsonian translocations are preferentially of paternal origin (Chamberlin and Magneis, 1980; Magenis and Chamberlin, 1981). An exception of this rule is del(15)(q11q13) in the Angelman syndrome in which all the deleted chromosomes 15 so far studied were maternally derived (Knoll et al., 1989). A suggestive evidence has been provided that the DNA at the 15q11-q13 region shows an unusual behavior through a genomic imprinting mechanism (Nicholls et al., 1989). Therefore, it is assumed that in the $\operatorname{del}(15)$ in the Angelman syndrome there exists an underlying unique mechanism prior to the breakage-reunion events.

The $\mathrm{i}(\mathrm{Xq})$ in patient III may have arisen through centromere fission of a maternal $\mathrm{X}$ chromosome, thus forming a telocentric chromosome, and subsequent fusion of the sister chromatids at the next replication (Van Dyke, 1988). Alternatively, it may have arisen through a translocation between the maternal homologous $\mathrm{X}$ chromosomes after crossing-over. The result suggests that the $\mathrm{i}(\mathrm{Xq})$ formation may have a mechanism similar to the formation of the centromere-fusion type of

Table 1. Informative genotypes of the present 4 patients and their parents, and parental origins and mechanisms of formation of the structural abnormalities.

\begin{tabular}{|c|c|c|c|c|c|c|c|}
\hline \multirow{2}{*}{$\begin{array}{l}\text { Case } \\
\text { No. }\end{array}$} & \multirow{2}{*}{ Abnormality } & \multicolumn{4}{|c|}{ Genotype } & \multirow{2}{*}{$\begin{array}{l}\text { Parental } \\
\text { origin }\end{array}$} & \multirow{2}{*}{$\begin{array}{l}\text { Mechanism of } \\
\text { formation }\end{array}$} \\
\hline & & Locus & Father & Mother & Patjent & & \\
\hline $\mathrm{I}$ & $\mathrm{X}, \operatorname{dup}(\mathrm{X})(\mathrm{p} 21)$ & DMD (Xp21) & $\mathrm{B} 2$ & $\mathrm{~B} 1 / \mathrm{B} 1$ & $\mathrm{~B} 1 / \mathrm{B} 2 / \mathrm{B} 2$ & Paternal & $\begin{array}{l}\text { Unequal sister } \\
\text { chromatid exchange }\end{array}$ \\
\hline II & $\mathrm{X}, \operatorname{del}(\mathrm{X})(\mathrm{p} 11)$ & p99-6(Xp22) & $\mathrm{A} 2$ & $\mathrm{~A} 1 / \mathrm{A} 1$ & $\mathrm{~A} 1 /-$ & Paternal & Interstitial deletion \\
\hline III & $\mathrm{X}, \mathrm{i}(\mathrm{Xq})$ & $\begin{array}{l}\text { DMD (Xp21) } \\
\text { DX13 (Xq28) }\end{array}$ & $\begin{array}{l}\mathrm{A} 2 \\
\mathrm{~B} 1\end{array}$ & $\begin{array}{l}\mathrm{A} 1 / \mathrm{A} 1 \\
\mathrm{~B} 1 / \mathrm{B} 2\end{array}$ & $\begin{array}{l}-/ \mathrm{A} 2 \\
\mathrm{~B} 1 / \mathrm{B} 1 / \mathrm{B} 1\end{array}$ & Maternal & $\begin{array}{l}\text { Centromere fission } \\
\text { and Xq duplication, } \\
\text { or translocation after } \\
\text { crossing-over }\end{array}$ \\
\hline IV & $\begin{array}{l}\text { X,inv } \operatorname{dup}(\mathrm{X}) \\
(\mathrm{q} 22)\end{array}$ & $\begin{array}{l}\text { pERT87-1 } \\
\text { pERT87-15 } \\
(\text { Xp21.2) }\end{array}$ & $\begin{array}{l}\text { A1 } \\
\text { B2 }\end{array}$ & $\begin{array}{l}\mathrm{A} 1 / \mathrm{A} 2 \\
\mathrm{~B} 1 / \mathrm{B} 2\end{array}$ & $\begin{array}{l}\mathrm{A} 1 / \mathrm{A} 2 / \mathrm{A} 2 \\
\mathrm{~B} 1 / \mathrm{B} 1 / \mathrm{B} 2\end{array}$ & Maternal & $\begin{array}{l}\text { Sister chromatid } \\
\text { breakage and } \\
\text { reunion }\end{array}$ \\
\hline
\end{tabular}

Symbols used for genotypes, except for those in patient IV, are identical to those in Fig. 1. 
Robertsonian translocation. Further studies are necessary on a number of nonmosaic iso $\mathrm{X}$ chromosomes using $\mathrm{Xq}$ probes near the centromere. The inv $\operatorname{dup}(\mathrm{X})$ in patient IV arose through sister chromatid breakage and reunion in a maternal $\mathrm{X}$ chromosome during oogenesis. This mechanism was the same as those in three reported cases of mos 45,X/46,X, dic(X)(q22) (Phelan et al., 1988).

In conclusion, the results of our study indicate that the mechanisms that form structural abnormalities are essentially the same between the autosomes and the $\mathrm{X}$ chromosome. Although the number of cases examined is small, the present results, together with those of the previous studies, also suggest that the events involving centromere disruption, i.e., nondisjunction and centromeric fission, occur predominantly during oogenesis, whereas simple breakage-reunion events occur preferentially during spermatogenesis. The latter rule was proposed for autosomes by Chamberlin and Magenis (1980) and again by Olson and Magenis (1988), and is supported by direct chromosome analysis of human spermatozoa, where structural abnormalities are much more frequent than numerical abnormalities (Kamiguchi and Mikamo, 1985). The testis, situated outside the abdomen, is largely unprotected against environmental changes, and the turn-over rate of its cells is high. The chromosomes of its cells are thus expected to be susceptible to environmental damages, such as those due to temperature changes and radiation.

Acknowledgments This study is supported by a Grant-in-Aid for Scientific Research from the Ministry of Education, Science and Culture of Japan (No. 63480472).

We express our gratitude to Drs. E. Bakker, K.E. Davies, L.M. Kunkel, R.M. Lawn, D.R. Maglott, J.-L. Mandel, P.L. Pearson, P.N. Ray, G.J.B. Van Ommen and R.G. Worton, and to Japanese Cancer Research Resources Bank (JCRB)-Gene and American Type Culture Collection (ATCC), for providing probes.

\section{REFERENCES}

Chamberlin, J. and Magenis, R.E. 1980. Parental origin of de novo chromosome rearrangements. Hum. Genet. 53: 343-347.

Deng, H.-X. and Niikawa, N. 1990. PvuII RFLPs in the DMD gene detected by a subclone (cDMD1a) of the cDNA. Nucleic Acids Res. 18: 3107.

Hassold, T., Chiu, D. and Yamane, J.A. 1984. Parental origin of autosomal trisomies. Ann. Hum. Genet. 48 : 129-144.

Hassold, T.J. and Jacobs, P.A. 1984. Trisomy in man. In Annual Review of Genetics, Vol, 18, Roman H.L., Campbell, A. and Sandler, L.M., eds., Annual Review, Inc., Palo Alto, pp. 69-97.

Hassold, T., Benham, F. and Leppert, M. 1988. Cytogenetic and molecular analysis of sex-chromosome monosomy. Am. J. Hum. Genet. 42: 534541.

Ishikiriyama, S. and Niikawa, N. 1984. Origin of extra chromosome in Patau syndrome. Hum. Genet. $68: 266-268$.

Juberg, R. and Mowrey, P.N. 1983. Origin of nondisjunction in trisomy 21 syndrome: All studies compiled, parental age analysis, and international comparisons. Am. J. Med. Genet. 16: 111116.

Kamiguchi, Y. and Mikamo, K. 1985. Application of developmental biotechnology to chromosome study of human spermatozoa. Jpn. J. Human Genet. 30: 85-87.

Knoll, J.H.M., Nicholls, R.D., Magenis, R.E., Graham, J.M., Jr., Lalande, M. and Latt, S.A. 1989. 
Angelman and Prader-Willi syndromes share a common chromosome 15 deletion but differ in parental origin of the deletion. Am. J. Med. Genet. 32: 285-290.

Kondoh, T., Tonoki, H., Matsumoto, T., Tsukahara, M. and Niikawa, N. 1988. Origin of the extra chromosome in trisomy 18. Hum. Genet. 79: 377-378.

Magenis, R.E. and Chamberlin, J. 1981. Parental origin of nondisjunction. In Trisomy 21 (Down syndrome). Research Perspectives. de la Cruz, F.F. and Gerald, P.S., eds., Univ. Park Press, Baltimore, pp. 77-93.

Magenis, R.E. 1988. On the origin of chromosome anomaly. Am. J. Hum. Genet. 42: 529-533.

Mandel, J.-L., Willard, H.F., Nussbaum, R.L., Romeo, G., Puck, J.M. and Davies, K.E. 1989. Report of the committee on the genetic constitution of the $\mathrm{X}$ chromosome. Tenth International Workshop on Human Gene Mapping. Cytogenet. Cell Genet. 51: 384-437.

Nicholls, R.D., Knoll, J.H.M., Butler, M.G., Karam, S. and Lalande, M. 1989. Genetic imprinting suggested by maternal heterodisomy in nondeletion Prader-Willi syndrome. Nature 342: 281-285.

Olson, S.B. and Magenis, R.E. 1988. Preferential paternal origin of de novo chromosome rearrangements. In The Cytogenetics of Mammalian Autosomal Rearrangements. Daniel, A., ed., Alan R. Liss, New York, pp. 583-599.

Phelan, M.C., Prouty, L.A., Stevenson, R.E., Howard-Peebles, P.N., Page, D.C. and Schwartz, C.E. 1988. The parental origin and mechanism of formation of three dicentric $\mathrm{X}$ chromosomes. Hum. Genet. 80: 81-84.

Stark, G.R., Debatisse, M., Giulotto, E. and Wahl, G.M. 1989. Recent progress in understanding mechanisms of mammalian DNA amplification. Cell 57: 901-908.

Stewart, G.D., Van Keuren, M.L., Galt, J., Kurachi, S., Buraczynska, M.J. and Kurnit, D.M. 1989. Molecular structure of human chromosome 21. In Annual Review of Genetics. Vol. 23, Campbell, A., Baker, B.S. and Herskowitz, I., eds., Annual Review, Inc., Palo Alto, pp. 409-423.

Van Dyke, D.L. 1988. Isochromosomes and interstitial tandem direct and inverted duplications. In The Cytogenetics of Mammalian Autosomal Rearrangements. Daniel, A., ed., Alan R. Liss, New York, pp. 635-666. 